\title{
Arctic Ocean Gas Hydrate Stability in a Changing Climate
}

\author{
Michela Giustiniani, ${ }^{1}$ Umberta Tinivella, ${ }^{1}$ Martin Jakobsson, ${ }^{2}$ and Michele Rebesco ${ }^{1}$ \\ ${ }^{1}$ National Institute of Oceanography and Experimental Geophysics (OGS), Borgo Grotta Gigante 42/C, 34010 Trieste, Italy \\ ${ }^{2}$ Department of Geological Sciences, Stockholm University, 10691 Stockholm, Sweden
}

Correspondence should be addressed to Michela Giustiniani; mgiustiniani@ogs.trieste.it

Received 26 June 2013; Accepted 17 September 2013

Academic Editor: Xuewei Liu

Copyright (C) 2013 Michela Giustiniani et al. This is an open access article distributed under the Creative Commons Attribution License, which permits unrestricted use, distribution, and reproduction in any medium, provided the original work is properly cited.

Recent estimations suggest that vast amounts of methane are locked in the Arctic Ocean bottom sediments in various forms of gas hydrates. A potential feedback from a continued warming of the Arctic region is therefore the release of methane to the atmosphere. This study addresses the relationship between a warming of the Arctic ocean and gas hydrate stability. We apply a theoretical model that estimates the base of the gas hydrate stability zone in the Arctic Ocean considering different bottom water warming and sea level scenarios. We model the present day conditions adopting two different geothermal gradient values: 30 and $40^{\circ} \mathrm{C} / \mathrm{km}$. For each geothermal gradient value, we simulate a rise and a decrease in seafloor temperature equal to $2^{\circ} \mathrm{C}$ and in sea level equal to $10 \mathrm{~m}$. The results show that shallow gas hydrates present in water depths less than $500 \mathrm{~m}$ would be strongly affected by a future rise in seafloor temperature potentially resulting in large amounts of gas released to the water column due to their dissociation. We estimate that the area, where there could be complete gas hydrate dissociation, is about $4 \%$ of the area where there are the conditions for gas hydrates stability.

\section{Introduction}

Vast quantities of methane are trapped in oceanic hydrate deposits, and there is a concern that a rise in the ocean temperature will induce dissociation of these hydrate accumulations, potentially releasing large amounts of methane into the atmosphere $[1,2]$. In this context, the Arctic should be considered a critical area in a warming climate because massive amounts of methane are currently locked as gas hydrates in ocean sediments and in permafrost that could be released [3-6]. Moreover, in the Arctic ocean, the gas hydrate stability zone is especially sensitive to climate change because the degree of temperature change is greater than at lower latitudes [4]. For example, the gas hydrate stability zone along continental slopes is found to be sensitive to even small changes in ocean bottom temperature [4], and the Arctic Ocean most likely has a larger gas hydrate stability zone compared to other oceans because of its cold water and low geothermal gradients [7]. However, it is still unclear whether the recent discoveries of methane emissions in the Arctic shelf and slope region are a result of better mapping and detection methods or whether they reflect a natural variability or environmental conditions following the present climate change.

Gas hydrates are solid crystalline compounds, in which gas molecules are lodged within the clathrate crystal lattice [8]. They occur when water and adequate quantity of gas combine under conditions of relatively high pressure and low temperature. The gas hydrate stability zone thickness varies widely within Arctic region depending on factors such as ocean bottom water/permafrost temperature, geothermal gradient, salinity of the water, and composition of gas [9].

Both permafrost-associated gas hydrates and the shallowest part of the deepwater marine gas hydrate system are susceptible to dissociation (breakdown to methane and water) under conditions of a warming Arctic climate. The dissociation of these hydrate deposits, which release large quantities of methane, could have dramatic climatic consequences that in turn lead to further atmospheric and oceanic warming through accelerated decomposition of the remaining hydrates [7]. This positive-feedback mechanism has been proposed as a significant contributor to rapid and 


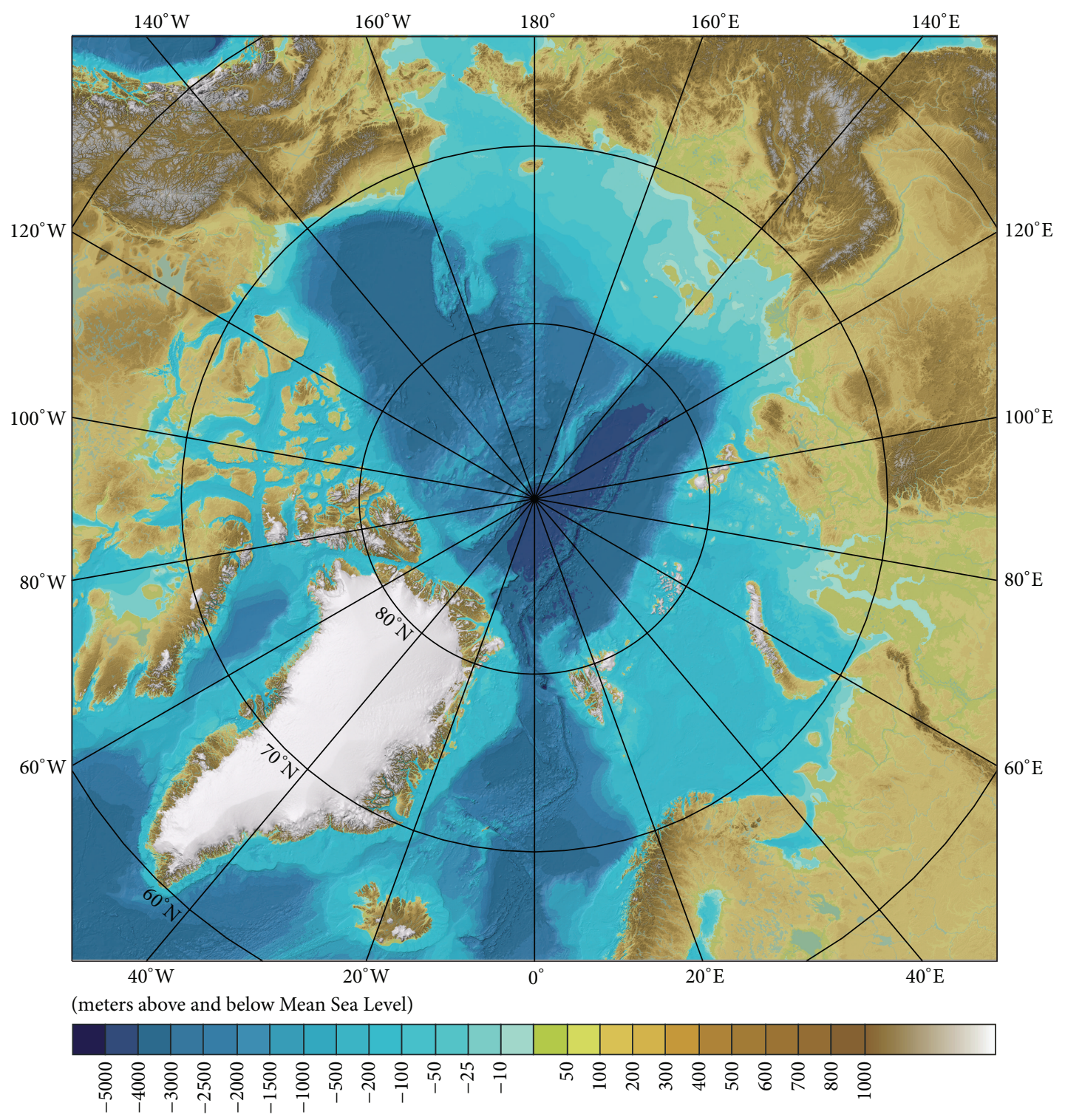

FIGURE 1: Map of investigated area including bathymetric data.

significant climate changes in the late Quaternary period [1013]. The "Clathrate Gun Hypothesis" [14] suggests that past increases in water temperatures near the seafloor may have induced such a large-scale dissociation, with the methane spike and isotopic anomalies reflected in polar ice cores and in benthic foraminifera [7]. Methane from dissociating hydrates in ocean sediments has been proposed to never reach the atmosphere, either due to its conversion to carbon dioxide in the water column or from being sequestered in the biosphere [15]. Isotopic studies of air trapped in ice cores question the source of the atmospheric methane during these rapid temperature excursions [16]. Furthermore, Nisbet [17], while suggesting methane as a factor in moderating glaciations, proposed that the methane spikes may follow, not lead, climate change. Simulations of deep ocean hydrates show that deep $(>1,000 \mathrm{~m})$ hydrates may be relatively insensitive to ocean temperature changes on short time scales. Dickens
[18] calculated that the volume of the GHSZ associated with marine hydrates halved during the Paleocene-Eocene thermal maximum with a temperature increase of $5^{\circ} \mathrm{C}$. Here, we define the area where there are the conditions for gas hydrates stability, and we model the effects of warmer ocean bottom temperatures and increased seafloor pressure on the gas hydrate stability zone (GHSZ) in the Arctic Ocean, as shown in Figure 1. Moreover, we focus on the intersection between the base of gas hydrate stability zone and the seafloor, identifying the areas where the complete dissociation of gas hydrates could occur and estimating their extension. The effects on the GHSZ from increased bottom temperatures have previously been modeled in the Antarctic Peninsula [19-21]. The base of GHSZ is calculated as the intersection between the geothermal curve and the gas hydrate stability curve $[22,23]$ by using the Sloan formula [8]. The following parameters were adopted to estimate the base of gas 
hydrate stability zone as described in the following sections: geothermal gradient, seafloor temperature, bathymetry, and gas composition.

\section{Gas Hydrates and the Arctic}

Many authors have demonstrated that climate change is occurring and is particularly pronounced in the Arctic [2426]. Because the Arctic plays a special role in global climate, these changes will also affect the rest of the world [27]. Global climate change is likely amplified in the Arctic by several positive feedbacks, including surface albedo decreased by ice and snow melting, temperature anomalies trapped near the surface by atmospheric stability, and change magnification by cloud dynamics $[28,29]$. Consequently, the temperature in the Arctic is increasing at a rate of two to three times that of the global temperature estimated to be $0.4^{\circ} \mathrm{C}$ over the past 150 years [30].

It is clear that the Arctic can contribute significantly to the amplification of climate changes. So, many efforts should be devoted to improve the knowledge about gas hydrate reservoir located in this area. It is clear that difficulty in carrying out seismic, bathymetric, and geological surveys has yielded little data about gas hydrates in the ice-covered Arctic basin [31]. Investigations are still producing surprising results indicating that our understanding of gas hydrate formation and distribution is incomplete [32]. The available estimates of methane in Arctic hydrates ranging between 1,013 and $1,016 \mathrm{~m}^{3}$ in onshore regions [33-36] are based mainly on speculations of constant distribution of hydrates within sediments across significant areas in a large depth interval using regional hydrate content percentage. An approach to obtain additional information about gas hydrate deposits, located in this area, could be the theoretical modeling of the GHSZ. In this context, we define the area where there are the conditions for gas hydrate stability zone and we simulate the effects of climate changes on hydrate. The base of the gas hydrate stability zone is calculated as the intersection between the geothermal gradient curve and gas-gas hydratepore water equilibrium curve. Moreover, we identify the area where the complete dissociation of gas hydrate could occur, if they were present.

As already mentioned, gas hydrate stability is mainly affected by ocean bottom water/permafrost temperature, geothermal gradient, salinity of the water, and composition of gas. It is known that the presence of only a small percentage of higher hydrocarbons (such as ethane and propane) shifts the phase boundary to higher temperature (at constant pressure). The effect is that the base of GHSZ at a given temperature is shifted to greater depths $[37,38]$.

\section{Gas Hydrates Modeling}

We consider the main factors affecting the GHSZ and simulate their variation analyzing the effects on gas hydrate stability. By using bathymetric data, sea bottom temperature, and geothermal gradient and considering that the natural gas is methane, we evaluate the theoretical GHSZ, similarly to what was recently evaluated in the Antarctic region by [1922]. The base of GHSZ was calculated as the intersection between the geothermal curve and the gas hydrate stability curve.

3.1. Seafloor Temperature. The seafloor temperature data are downloaded from the National Oceanographic Data Center website (http://www.nodc.noaa.gov/cgi-bin/OC5/WOA09/ woa09.pl). The available water temperatures were sampled at 33 different depths (from 0 to 5,500 m) on one-degree fields. The intersection between the 33 levels and the bathymetric data allow us to extract the seafloor temperature. In this way, we obtained the distribution of seafloor temperature in study area shown in Figure 2.

3.2. Pressure Based on Water Depth. An important factor considered in GHSZ estimation is the water depth because its variation strongly affects the GHSZ thickness especially for deep gas hydrate reservoir $(>500 \mathrm{~m})$. The adopted digital bathymetric model was developed by the International Bathymetric Chart of the Arctic Ocean (IBCAO) project (http://www.ngdc.noaa.gov/mgg/bathymetry/arctic/ downloads.html). The IBCAO map (version 3) is a seamless bathymetric topographic digital terrain model that incorporates three primary data sets: all available bathymetric data; the GMTED 2010 topographic data; and the World Vector Shoreline for coastline representation [39]. The grid cell size of the adopted version is $2 \times 2 \mathrm{~km}$ on a polar stereographic projection. The bathymetric data are translated in terms of pressure considering the average water density equal to $1,046 \mathrm{~kg} / \mathrm{m}^{3}$. We extrapolate the average water density as suggested by Giorgetti et al. [40] for Antarctic Peninsula because of the similarity of water temperature and polar climate conditions.

3.3. Gas Composition. Knowledge about gas composition of gas hydrates is always poor. In our study, we suppose that the component of gas is pure methane. In this way, we consider the condition for which the base of GHSZ is shallower, so more sensitive to climate changes.

3.4. Geothermal Gradients. The Arctic region lacks geothermal gradient data because of the difficulty to acquire data. So, we consider the following geothermal gradients: 30 and $40^{\circ} \mathrm{C} / \mathrm{km}$, considering different studies [41, 42]. As suggested by different authors $[43,44]$, the geothermal gradients can highly range due to different factors such as presence of mud diapirs or salt domes, inversion of the basin resulting in shallow basement rocks, and presence of faults causing focused fluid flow [42]. As previously demonstrated [45] zones characterized by lower geothermal gradients, are more affected by climate change concerning gas hydrate stability.

The base of the GHSZ is estimated as the intersection between geothermal curve and the gas hydrate stability curve calculated using the Sloan formula [8]. First, we simulate the present day condition using the collected parameters to evaluate the zone where there are the conditions for gas 


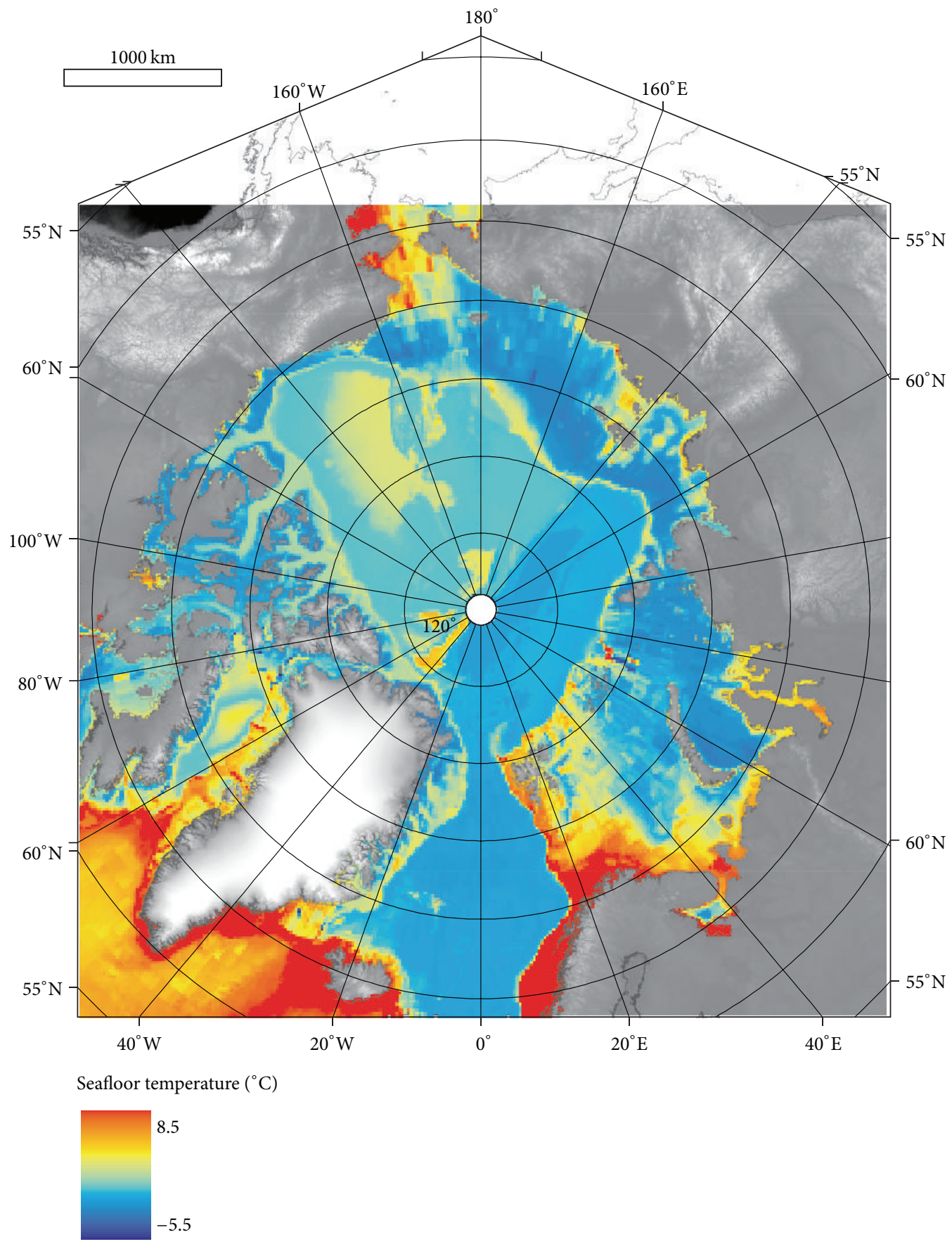

Figure 2: Seafloor temperature $\left({ }^{\circ} \mathrm{C}\right)$ (data processed after downloading from National Oceanographic Data Center website).

hydrate stability. For each geothermal gradient value, we then simulate a rise and a decrease in seafloor temperature equal to $2^{\circ} \mathrm{C}$ and in sea level equal to $10 \mathrm{~m}$. The rise in seafloor temperature of $2^{\circ} \mathrm{C}$ is in agreement with temperatures during the latest Paleocene thermal maximum. In fact, the end of the Paleocene epoch was marked by an abrupt episode of global warming coincident with a large perturbation of the global carbon cycle [46]. Within 10 to $30 \mathrm{ky}[47,48]$, temperatures increased 4 to $5^{\circ} \mathrm{C}$ in the tropics $[49,50], 6$ to $8^{\circ} \mathrm{C}$ in high latitudes [51], and 4 to $5^{\circ} \mathrm{C}$ in the deep ocean $[52,53]$. The decrease in seafloor temperature is considered to simulate a glacial period. Moreover, results from recent simulations coupling circulation, atmospheric circulation, and atmospheric chemistry (publications in CCSM, 2006) indicate that, under current climate conditions and $1 \%$ yr increase in atmospheric $\mathrm{CO}_{2}$, the temperature at the seafloor would rise by $1^{\circ} \mathrm{C}$ over the next 100 years and possibly by another $3^{\circ} \mathrm{C}$ in the following centuries [7]. Regarding the sea-level change, 

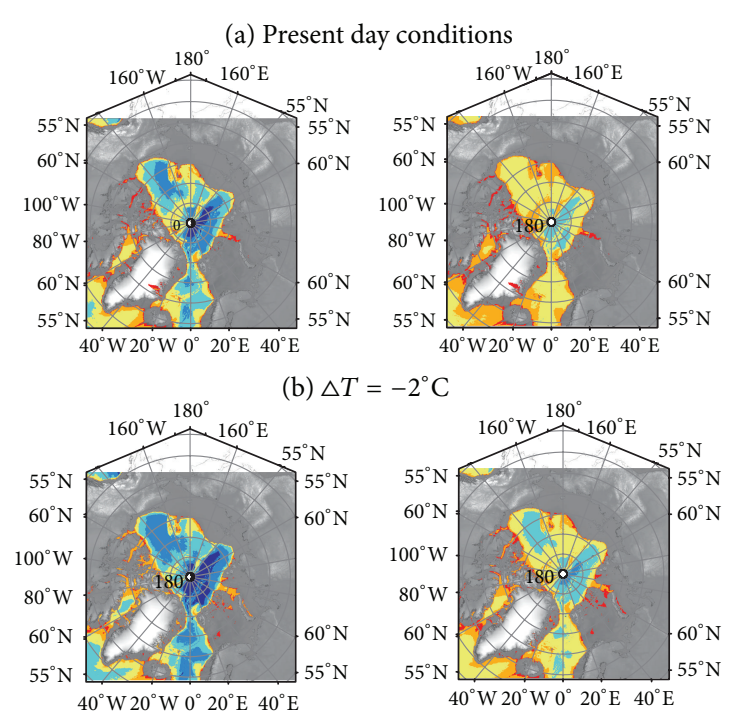

(c) $\triangle T=+2^{\circ} \mathrm{C}$

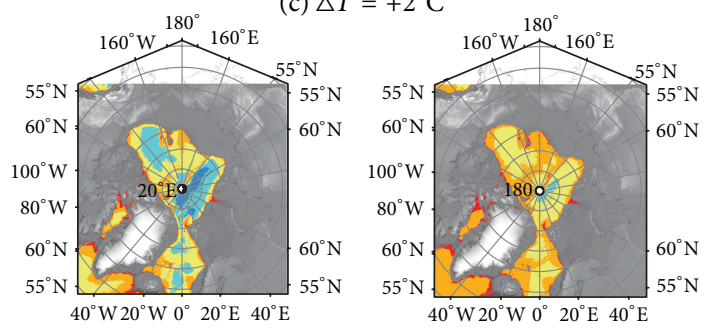

(d) $\triangle Z=-10$

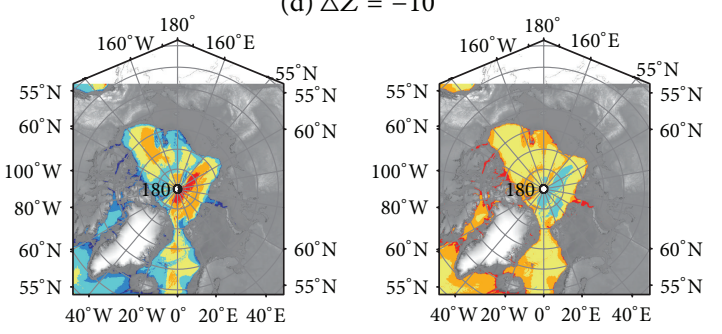

(e) $\triangle Z=+10$
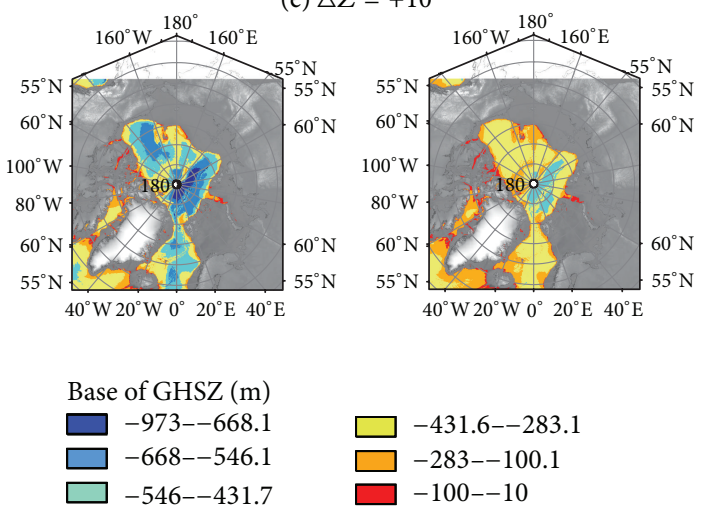

FIGURE 3: Depth of base of GHSZ from seafloor. In each panel, the left modeling was performed by using a geothermal gradient equal to $30^{\circ} \mathrm{C} / \mathrm{km}$, while, for the right panel, the geothermal gradient was $40^{\circ} \mathrm{C} / \mathrm{km}$. For details see the text.

the range of future climate-induced sea-level rise remains uncertain with continued concern that large increases in the twenty-first century cannot be ruled out. The mean rate of sea-level rate measured by high-precision altimeter amounts to $3.3 \pm 0.4 \mathrm{~mm}$ /year from 1993 to 2009 , suggesting that sealevel rate is accelerating compared to the past [54]. Moreover, there is a huge uncertainty due to the potential melting of glaciers, and the possible role of the Greenland and West 


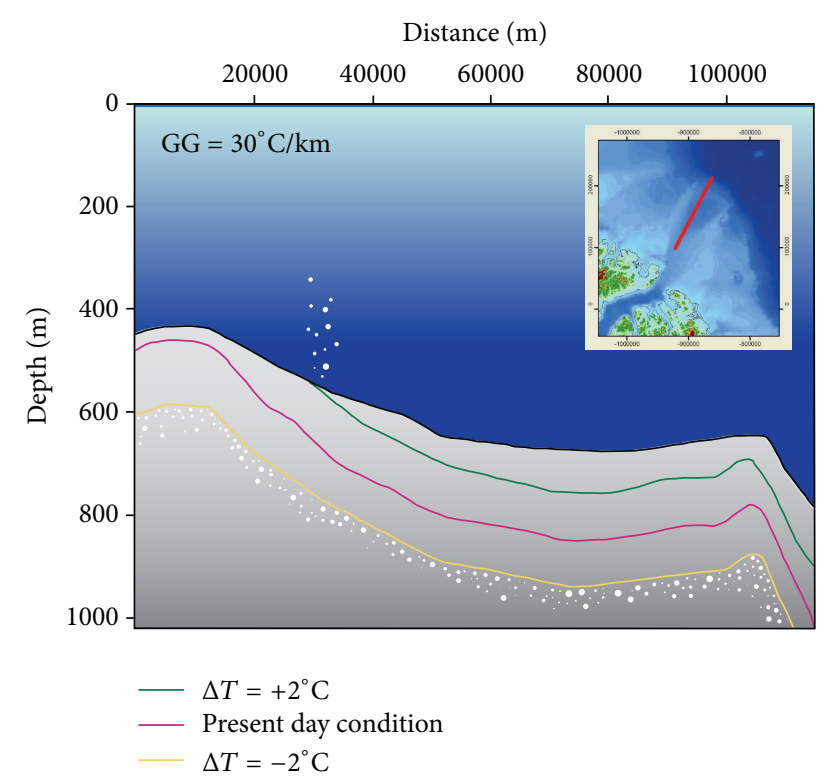

FIGURE 4: Selected profile offshore Svalbard Island. The black line represents the present day topography along the profile. The shown simulations are performed using a geothermal gradient (GG) equal to $30^{\circ} \mathrm{C} / \mathrm{km}$.

Antarctic ice sheets, which could amplify the changes in sea level. The Intergovernmental Panel on Climate Change (IPCC) has pointed out that for a warming over Greenland of $5.5^{\circ} \mathrm{C}$ the Greenland ice sheet contribution is about $3 \mathrm{~m}$ in 1,000 years, while for a warming of $8^{\circ} \mathrm{C}$ the contribution is about $6 \mathrm{~m}$, with the ice sheet being largely eliminated. So, considering $10 \mathrm{~m}$ of sea-level variation, it is likely to predict an extreme scenario, but not unrealistic [30]. Anyway, several models have suggested that the sea level dropped by about $100 \mathrm{~m}$ during the last glacial maximum [55]. Rohling et al. [56] suggested that the sea level was $120 \mathrm{~m}$ below its present value during the last glacial maximum reducing the watercovered shelf and marginal sea areas by approximately $50 \%$ [57-59].

\section{Discussions}

We show the modeled base of the GHSZ for all 10 cases analyzed in Figure 3, showing the depth of the base of GHSZ from seafloor. We modeled 5 cases for each geothermal gradient value. Panel (a) shows present day conditions; panel (b) shows temperature decrease of 2 degrees; and panel (c) shows temperature increase, while panels (d) and (e) show decrease and increase of sea level, respectively. As previously mentioned, the base of GHSZ is calculated as the intersection between the gas hydrate stability curve and the geothermal curve. The base of GHSZ is commonly inferred from seismic reflection profiles using a bottom simulating reflector (BSR), which is the boundary between hydrate-bearing sediment above and gassy sediment beneath [60]. As expected, a rise in seafloor temperature causes gas hydrate in the region to become unstable (panel (c) in Figure 3). This could cause the base of the GHSZ to move upward resulting in thinner GHSZ and subsequent methane releases. On the contrary, a decrease in seafloor temperature could cause the base of the GHSZ to move downward. In this condition, the GHSZ could increase in thickness as shown in panel (b). A negative feedback from a warming climate is a rising sea level from melting of glaciers and ice sheets, which would increase the pressure at the seafloor. This could result in the deepening of the base of the GHSZ extending the zone where there are the conditions for gas hydrate stability, as shown in column (e) of Figure 3. On the contrary, the decrease of sea level lead to a shallower base of the GHSZ. However, the effect of $10 \mathrm{~m}$ sea-level change on gas stability zone is very low compared to those of a 2-degree temperature change. In Figure 4, we show a profile offshore Svalbard Island, considering the case for which the geothermal gradient is equal to $30^{\circ} \mathrm{C} / \mathrm{km}$.

The black line represents the bathymetry along the profile. Below it, we show three hypothetical future scenarios, which will affect gas hydrate stability: (a) present day condition (purple line), (b) considering a rise of $2^{\circ} \mathrm{C}$ (green line), and (c) considering a decrease of $2^{\circ} \mathrm{C}$ (yellow line). The modeling shows clearly that a rise in temperature could affect the gas hydrate reservoir in this location and cause dissociation. In fact, where the depth is deeper than $500 \mathrm{~m}$, as shown in Figure 4 , an increase of $2^{\circ} \mathrm{C}$ in seafloor temperature could cause the complete dissociation of gas hydrate releasing methane in the water column and, maybe, in the atmosphere. Moreover, the free gas trapped below the gas hydrate reservoir could also be released. When there is a partial dissociation of gas hydrates, that is, gas hydrate in water depth shallower than $500 \mathrm{~m}$, because of the increase in temperature or/and the decrease of sea level, there may also be a positive feedback on climate. In fact, the free gas released from gas hydrate dissociation, will be trapped in the sediments because gas hydrate will act as cap. To contribute to the estimation of the effects of gas hydrate on climate change, we identify the area, where there could be a complete gas hydrate dissociation because of a rise of $2^{\circ} \mathrm{C}$ in sea bottom temperature, and estimate its extension equal to $3.1 \times 10^{5} \mathrm{~km}^{2}$ (Figure 5). This area represents about $4 \%$ of the area where there are the conditions for gas hydrates stability. To estimate this area, we calculate the present day intersection between the seafloor and the base of gas hydrate zone and that one considering a rise in seafloor temperature equal to $2^{\circ} \mathrm{C}$. In the zone included between the two intersections, there could be a complete dissociation of gas hydrate as shown in Figure 5.

\section{Conclusions}

Our modeling confirms that the shallow gas hydrate deposits (water column $<500 \mathrm{~m}$ ) could be strongly affected by climate change, mainly by rise in temperature and that methane could be released due to gas hydrate dissociation. It is important to underline that several factors mitigate the impact of the 


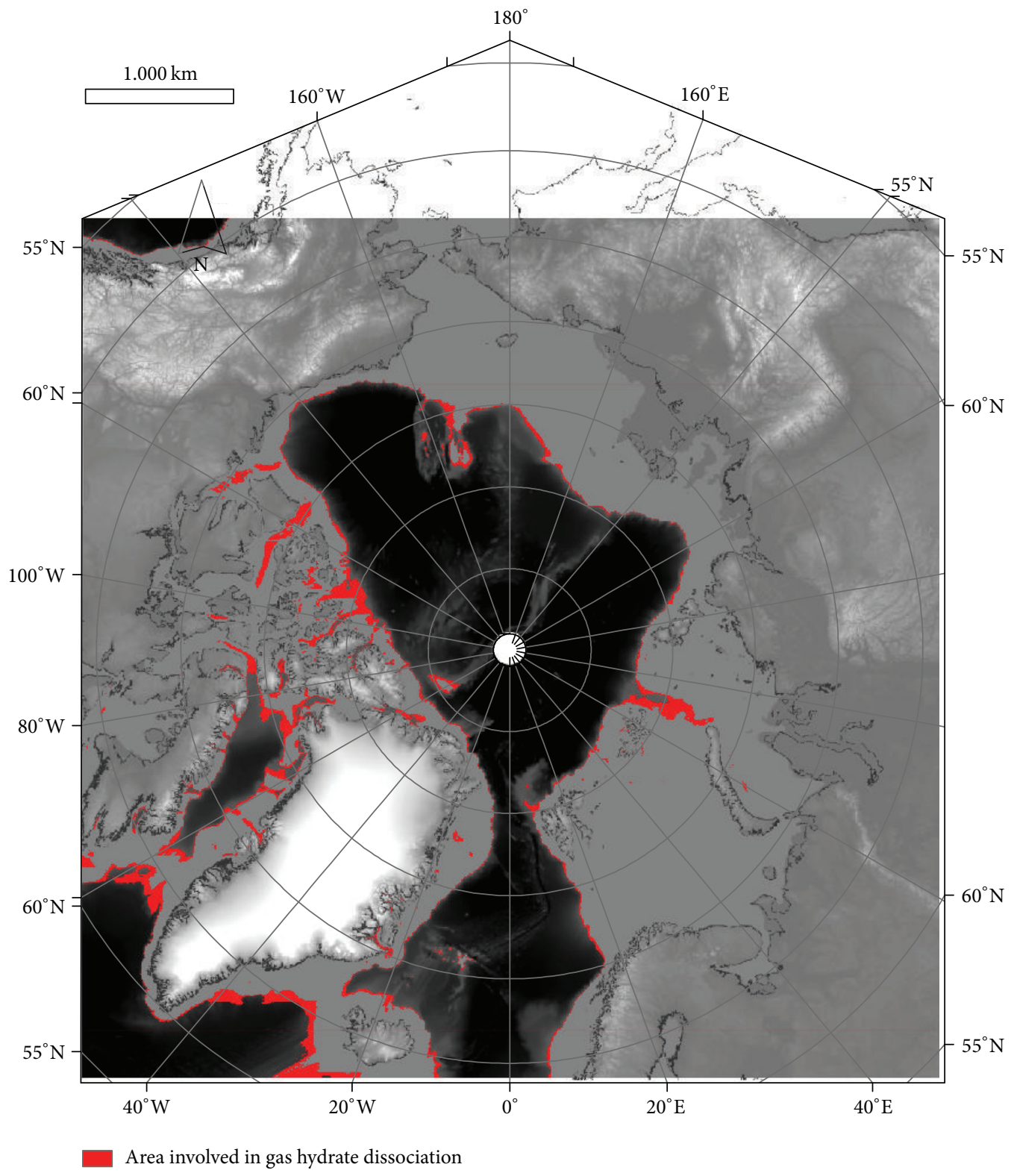

FiguRE 5: In the red areas, complete dissociation of gas hydrate could talk place with a rise in the seafloor temperature of $2^{\circ} \mathrm{C}$. This simulation is performed using a geothermal gradient of $30^{\circ} \mathrm{C} / \mathrm{km}$.

liberated $\mathrm{CH}_{4}$ on the sediment-ocean-atmosphere system. The released $\mathrm{CH}_{4}$ may dissolve in local pore waters, remain trapped as gas, or rise toward the seafloor as bubbles. Up to $90 \%$ or more of the $\mathrm{CH}_{4}$ that reaches the sulfate reduction zone in the near-seafloor sediments may be consumed by anaerobic $\mathrm{CH}_{4}$ oxidation [61-65]. Moreover, methane emitted at the seafloor only rarely survives the trip through the water column to reach the atmosphere. In fact, within the water column, oxidation by aerobic microbes is an important sink for dissolved $\mathrm{CH}_{4}$ over some depth ranges and at some locations (e.g., [66]).

Since authors predict the current and near-future evolution of sea-level rise remain in the range of few decimeters
[54, 67], it is mainly the warming of the oceans that has the potential to significantly alter the stable conditions of methane hydrates [68]. So many efforts should be devoted to improve the knowledge about the Arctic gas hydrate reservoirs, because they could play an important role regarding world warming changes, considering that over the past decade the Arctic has been warming up twice as fast as the global average [69]. Moreover, we should improve the knowledge about shallow gas hydrate deposits (water column $<500 \mathrm{~m}$ ) which could be completely dissociated determining a change of the characteristics of the underground with unpredictable effects. Finally, it is worth to mention that the Arctic is an area logistically difficult to investigate due 
to the extreme environmental conditions. So, modeling is indispensable for planning and identifying the key areas, where more accurate field analyses should be performed. When more detailed data about gas hydrate occurrence will be available, our modeling can be used to extrapolate local information at global scale.

\section{Acknowledgment}

The authors wish to thank Manuela Sedmach for the graphic support.

\section{References}

[1] M. T. Reagan and G. J. Moridis, "Large-scale simulation of methane hydrate dissociation along the West Spitsbergen Margin," Geophysical Research Letters, vol. 36, no. 23, Article ID L23612, 2009.

[2] M. T. Reagan, G. J. Moridis, S. M. Elliott, and M. Maltrud, “Contribution of oceanic gas hydrate dissociation to the formation of Arctic Ocean methane plumes," Journal of Geophysical Research C, vol. 116, no. 9, Article ID C09014, 2011.

[3] N. Shakhova, I. Semiletov, A. Salyuk, V. Yusupov, D. Kosmach, and Ö. Gustafsson, "Extensive methane venting to the atmosphere from sediments of the East Siberian Arctic Shelf," Science, vol. 327, no. 5970, pp. 1246-1250, 2010.

[4] G. K. Westbrook, K. E. Thatcher, E. J. Rohling et al., "Escape of methane gas from the seabed along the West Spitsbergen continental margin," Geophysical Research Letters, vol. 36, no. 15, Article ID L15608, 2009.

[5] B. Buffett and D. Archer, "Global inventory of methane clathrate: sensitivity to changes in the deep ocean," Earth and Planetary Science Letters, vol. 227, no. 3-4, pp. 185-199, 2004.

[6] E. A. G. Schuur, J. G. Vogel, K. G. Crummer, H. Lee, J. O. Sickman, and T. E. Osterkamp, "The effect of permafrost thaw on old carbon release and net carbon exchange from tundra," Nature, vol. 459, no. 7246, pp. 556-559, 2009.

[7] M. T. Reagan and G. J. Moridis, "Oceanic gas hydrate instability and dissociation under climate change scenarios," Geophysical Research Letters, vol. 34, no. 22, Article ID L22709, 2007.

[8] E. D. Sloan, Clathrate Hydrates of Natural Gases, Marcel Dekker, New York, NY, USA, 2nd edition, 1998.

[9] E. D. Sloan, "Natural gas hydrate phase equilibria and kinetics: understanding the state-of-the-art," Revue de l'Institut Francais du Petrole, vol. 45, no. 2, pp. 245-266, 1990.

[10] J. P. Kennett, K. G. Cannariato, I. L. Hendy, and R. J. Behl, "Carbon isotopic evidence for methane hydrate instability during quaternary interstadials," Science, vol. 288, no. 5463, pp. 128-133, 2000.

[11] E. J. Brook, T. Sowers, and J. Orchardo, "Rapid variations in atmospheric methane concentration during the past 110,000 years," Science, vol. 273, no. 5278, pp. 1087-1091, 1996.

[12] J. P. Severinghaus, T. Sowers, E. J. Brook, R. B. Alley, and M. L. Bender, "Timing of abrupt climate change at the end of the Younger Dryas interval from thermally fractionated gases in polar ice," Nature, vol. 391, no. 6663, pp. 141-146, 1998.

[13] R. J. Behl, J. P. Kennett, K. G. Cannariato, and L. L. Hendy, "Methane hydrates and climate change: the clathrate gun hypothesis," AAPG Bulletin, vol. 87, no. 10, article 1693, 2003.
[14] J. P. Kennett, K. G. Cannariato, I. L. Hendy, and R. J. Behl, Methane Hydrates in Quaternary Climate Change: The Clathrate Gun Hypothesis, vol. 54, American Geophysical Union, Washington, DC, USA, 2002.

[15] K. A. Kvenvolden, "Potential effects of gas hydrate on human welfare," Proceedings of the National Academy of Sciences of the United States of America, vol. 96, no. 7, pp. 3420-3426, 1999.

[16] T. Sowers, "Late quaternary atmospheric $\mathrm{CH}_{4}$ isotope record suggests marine clathrates are stable," Science, vol. 311, no. 5762, pp. 838-840, 2006.

[17] E. G. Nisbet, "Have sudden large releases of methane from geological reservoirs occurred since the Last Glacial Maximum, and could such releases occur again?" Philosophical Transactions of the Royal Society A, vol. 360, no. 1793, pp. 581-607, 2002.

[18] G. R. Dickens, "The potential volume of oceanic methane hydrates with variable external conditions," Organic Geochemistry, vol. 32, no. 10, pp. 1179-1193, 2001.

[19] U. Tinivella, "The seismic response to overpressure versus gas hydrate and free gas concentration," Journal of Seismic Exploration, vol. 11, no. 3, pp. 283-305, 2002.

[20] M. Giustiniani, D. Accettella, M. F. Loreto, U. Tinivella, and F. Accaino, "Geographic information system-an application to manage geophysical data," in Proceedings of the 71st European Association of Geoscientists and Engineers Conference and Exhibition, pp. 340-344, Society of Petroleum Engineers, Amsterdam, The Netherlands, June 2009.

[21] U. Tinivella, M. Giustiniani, and D. Accettella, "BSR versus climate change and slides," Journal of Geological Research, vol. 2011, Article ID 390547, 6 pages, 2011.

[22] U. Tinivella and J. M. Carcione, "Estimation of gas-hydrate concentration and free-gas saturation from log and seismic data," The Leading Edge, vol. 20, no. 2, pp. 200-203, 2001.

[23] M. F. Loreto, U. Tinivella, F. Accaino, and M. Giustiniani, "Offshore Antarctic Peninsula gas hydrate reservoir characterization by geophysical data analysis," Energies, vol. 4, no. 1, pp. 39-56, 2011.

[24] D. Antoniades, P. Francus, R. Pienitz, G. St-Onge, and W. F. Vincent, "Holocene dynamics of the Arctic's largest ice shelf," Proceedings of the National Academy of Sciences of the United States of America, vol. 108, no. 47, pp. 18899-18904, 2011.

[25] B. M. Vinther, S. L. Buchardt, H. B. Clausen et al., "Holocene thinning of the Greenland ice sheet," Nature, vol. 461, no. 7262, pp. 385-388, 2009.

[26] R. G. Graversen, T. Mauritsen, M. Tjernström, E. Källén, and G. Svensson, "Vertical structure of recent Arctic warming," Nature, vol. 451, no. 7174, pp. 53-56, 2008.

[27] ACIA, "Arctic Climate Impact Assessment," ACIA Scientific Report, Cambridge University Press, Cambridge, UK, 2005.

[28] J. Overpeck, K. Hughen, D. Hardy et al., "Arctic environmental change of the last four centuries," Science, vol. 278, no. 5341, pp. 1251-1256, 1997.

[29] P. R. Gent, "Preface to special issue on Community Climate System Model (CCSM)," Journal of Climate, vol. 19, no. 11, article 2121, 2006.

[30] S. Solomon, D. Qin, M. Manning et al., Eds., "Climate change 2007: the physical science basis. Contribution of working group I to the fourth assessment report of the Intergovernmental Panel on Climate Change," Assessment Report, Cambridge University Press, Cambridge, UK, 2007.

[31] C. J. Willmott, S. M. Robeson, and K. Matsuura, "Short communication A refined index of model performance," International Journal of Climatology, vol. 32, pp. 2088-2094, 2012. 
[32] G. A. Cherkashov and T. Matveeva, "Undiscovered Arctic gas hydrates: permafrost relationship and resource evaluation," in Proceedings of the American Geophysical Union, Fall Meeting, San Francisco, Calif, USA, December 2011, abstract \#GC52A-01.

[33] V. M. Dobrynin, Y. P. Korotajeva, and D. V. Plyuschev, "Gas hydrates-one of the possible energy sources," in Long-Term Energy Resources, R. G. Meyer and J. C. Olson, Eds., pp. 727729, Pitman, Boston, Mass, USA, 1981.

[34] K. A. Kvenvolden, "Methane hydrate-a major reservoir of carbon in the shallow geosphere?" Chemical Geology, vol. 71, no. 1-3, pp. 41-51, 1988.

[35] G. J. MacDonald, "Role of methane clathrates in past and future climates," Climatic Change, vol. 16, no. 3, pp. 247-281, 1990.

[36] R. D. McIver, "Gas hydrates," in Long-Term Energy Resources, R. G. Meyer and J. C. Olson, Eds., pp. 713-726, Pitman, Boston, Mass, USA, 1981

[37] G. D. Holder, R. D. Malone, and W. F. Lawson, "Effects of gas composition and geothermal properties on the thickness and depth of natural-gas-hydrate zones," Journal of Petroleum Technology, vol. 39, no. 9, pp. 1147-1152, 1987.

[38] E. D. Sloan and C. A. Koh, Clathrate Hydrates of Natural Gases, CRC Press, Boca Raton, Fla, USA, 3rd edition, 2008.

[39] M. Jakobsson, L. Mayer, B. Coakley et al., "The International Bathymetric Chart of the Arctic Ocean (IBCAO) version 3.0," Geophysical Research Letters, vol. 39, no. 12, Article ID L12609, 2012.

[40] A. Giorgetti, A. Crise, R. Laterza, L. Perini, M. Rebesco, and A. Camerlenghi, "Water masses and bottom boundary layer dynamics above a sediment drift of the Antarctic Peninsula pacific margin," Antarctic Science, vol. 15, no. 4, pp. 537-546, 2003.

[41] F. W. Jones, J. A. Majorowicz, J. Dietrich, and A. M. Jessop, "Geothermal gradients and heat flow in the BeaufortMackenzie Basin, Arctic Canada," Pure and Applied Geophysics, vol. 134, no. 3, pp. 473-483, 1990.

[42] S. Chand, J. Mienert, K. Andreassen, J. Knies, L. Plassen, and B. Fotland, "Gas hydrate stability zone modelling in areas of salt tectonics and pockmarks of the Barents Sea suggests an active hydrocarbon venting system," Marine and Petroleum Geology, vol. 25, no. 7, pp. 625-636, 2008.

[43] C. Ruppel, G. R. Dickens, D. G. Castellini, W. Gilhooly, and D. Lizarralde, "Heat and salt inhibition of gas hydrate formation in the northern Gulf of Mexico," Geophysical Research Letters, vol. 32, no. 4, pp. 1-4, 2005.

[44] T. Bugge, G. Elvebakk, S. Fanavoll et al., "Shallow stratigraphic drilling applied in hydrocarbon exploration of the Nordkapp Basin, Barents Sea," Marine and Petroleum Geology, vol. 19, no. 1, pp. 13-37, 2002.

[45] U. Tinivella and M. Giustiniani, "Variations in BSR depth due to gas hydrate stability versus pore pressure," Global and Planetary Change, vol. 100, pp. 119-128, 2013.

[46] J. A. Higgins and D. P. Schrag, "Beyond methane: towards a theory for the Paleocene-Eocene thermal maximum," Earth and Planetary Science Letters, vol. 245, no. 3-4, pp. 523-537, 2006.

[47] U. Röhl, T. J. Bralower, R. D. Norris, and G. Wefer, "New chronology for the late Paleocene thermal maximum and its environmental implications," Geology, vol. 28, no. 10, pp. 927-930, 2000.

[48] K. A. Farley and S. F. Eltgroth, "An alternative age model for the Paleocene-Eocene thermal maximum using extraterrestrial 3He," Earth and Planetary Science Letters, vol. 208, no. 3-4, pp. 135-148, 2003.
[49] J. C. Zachos, M. W. Wara, S. Bohaty et al., "A transient rise in tropical sea surface temperature during the Paleocene-Eocene thermal maximum," Science, vol. 302, no. 5650, pp. 1551-1554, 2003.

[50] A. Tripati and H. Elderfield, "Paleoclimate: deep-sea temperature and circulation changes at the Paleocene-Eocene thermal maximum," Science, vol. 308, no. 5730, pp. 1894-1898, 2005.

[51] E. Thomas and N. J. Shackleton, "The latest Paleocene benthic foraminiferal extinction and stable isotope anomalies," in Correlation of the Early Paleogene in Northwest Europe, R. O. Knox, R. M. Corfield, and R. E. Dunay, Eds., vol. 101 of Geological Society Special Publication, pp. 401-441, Geological Society of London, London, UK, 1996.

[52] J. C. Zachos, K. C. Lohmann, J. C. G. Walker, and S. W. Wise, "Abrupt climate change and transient climates during the Paleogene: a marine perspective," Journal of Geology, vol. 101, no. 2, pp. 191-213, 1993.

[53] J. P. Kennett and L. D. Stott, "Abrupt deep-sea warming, palaeoceanograph-ic changes and benthic extinctions at the end of the Palaeocene," Nature, vol. 353, no. 6341, pp. 225-229, 1991.

[54] R. J. Nicholls and A. Cazenave, "Sea-level rise and its impact on coastal zones," Science, vol. 328, no. 5985, pp. 1517-1520, 2010.

[55] M. J. Bentley, "Volume of Antarctic ice at the last glacial maximum, and its impact on global sea level change," Quaternary Science Reviews, vol. 18, no. 14, pp. 1569-1595, 1999.

[56] E. J. Rohling, M. Fenton, F. J. Jorissen, P. Bertrand, G. Ganssen, and J. P. Caulet, "Magnitudes of sea-level lowstands of the past 500,000 years," Nature, vol. 394, no. 6689, pp. 162-165, 1998.

[57] H. W. Menard and S. M. Smith, "Hypsometry of ocean basin provinces," Journal of Geophysical Research, vol. 71, no. 18, pp. 4305-4325, 1966.

[58] W. R. Peltier, “Ice age paleotopography," Science, vol. 265, no. 5169, pp. 195-201, 1994.

[59] W. Ludwig, P. Amiotte-Suchet, and J.-L. Probst, "Enhanced chemical weathering of rocks during the last glacial maximum: a sink for atmospheric $\mathrm{CO}_{2}$ ?" Chemical Geology, vol. 159, no. 1-4, pp. 147-161, 1999.

[60] T. H. Shipley, M. H. Houston, R. T. Buffler et al., "Seismic reflection evidence for widespread occurrence of possible gashydrate horizons on continental slopes and rises," American Association of Petroleum Geologists Bulletin, vol. 63, pp. 22042213, 1979.

[61] K.-U. Hinrichs and A. Boetius, "The anaerobic oxidation of methane: new insights in microbial ecology and biochemistry," in Ocean Margin Systems, G. Wefer, D. Billet, D. Hebbeln, B. B. Jorgensen, M. Schlüter, and T. C. E. V. Weering, Eds., pp. 457477, Springer, Berlin, Germany, 2002.

[62] T. Treude, A. Boetius, K. Knittel et al., "Anaerobic oxidation of methane at Hydrate Ridge (OR)," Geochimica et Cosmochimica Acta, vol. 67, article A491, 2003.

[63] W. S. Reeburgh, "Oceanic methane biogeochemistry," Chemical Reviews, vol. 107, no. 2, pp. 486-513, 2007.

[64] K. Knittel and A. Boetius, "Anaerobic oxidation of methane: progress with an unknown process," Annual Review of Microbiology, vol. 63, pp. 311-334, 2009.

[65] C. D. Ruppel, "Methane hydrates and contemporary climate change," Nature Education Knowledge, vol. 3, no. 10, article 29, 2011.

[66] S. Mau, D. L. Valentine, J. F. Clark, J. Reed, R. Camilli, and L. Washburn, "Dissolved methane distributions and air-sea flux in the plume of a massive seep field, Coal Oil Point, California," 
Geophysical Research Letters, vol. 34, no. 22, Article ID L22603, 2007.

[67] J. A. Church, N. J. White, L. F. Konikow et al., "Revisiting the Earth's sea-level and energy budgets from 1961 to 2008," Geophysical Research Letters, vol. 38, no. 18, Article ID L18601, 2011.

[68] A. Biastoch, T. Treude, L. H. Rüpke et al., "Rising Arctic Ocean temperatures cause gas hydrate destabilization and ocean acidification," Geophysical Research Letters, vol. 38, no. 8, Article ID L08602, 2011.

[69] J. Hansen, M. Sato, R. Ruedy et al., "Dangerous human-made interference with climate: a GISS modelE study," Atmospheric Chemistry and Physics, vol. 7, no. 9, pp. 2287-2312, 2007. 

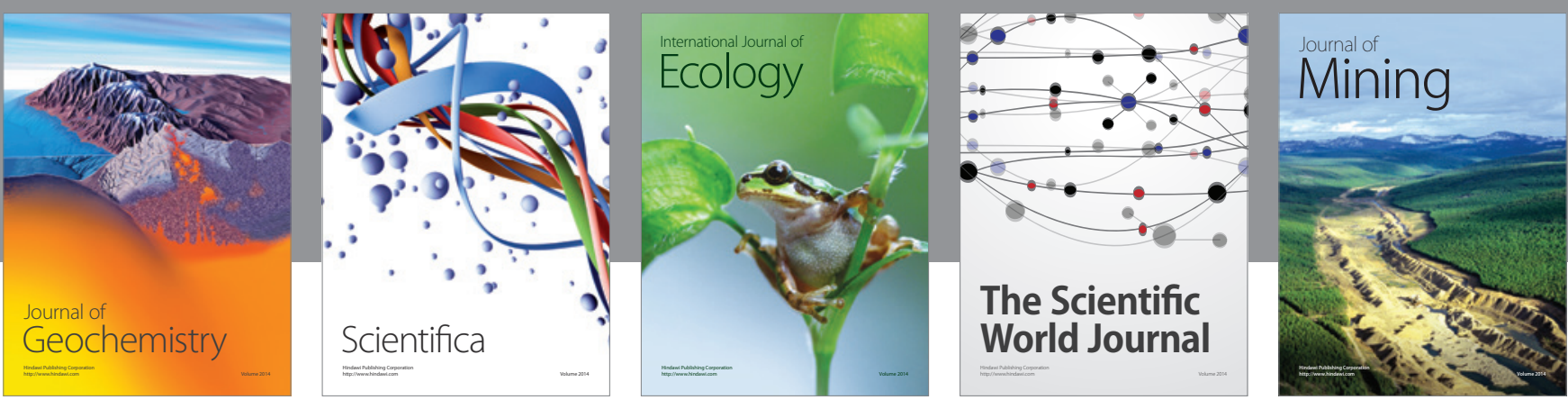

The Scientific World Journal
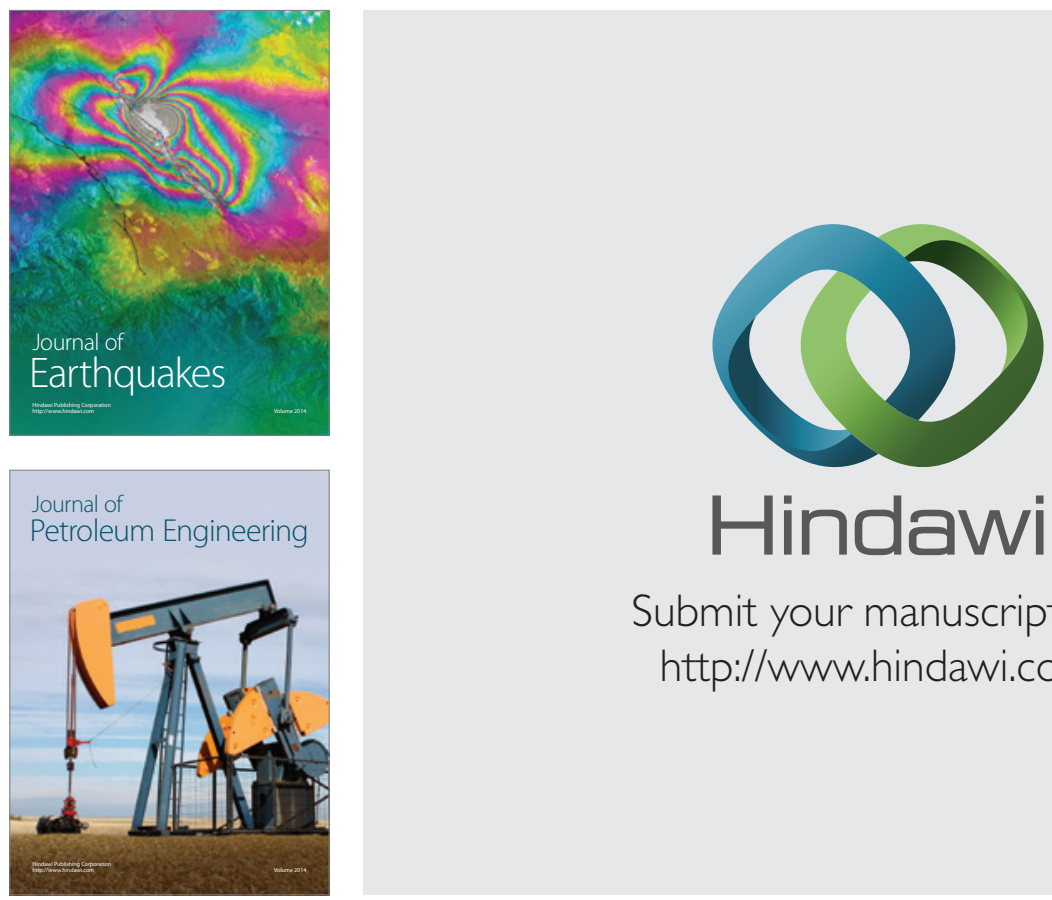

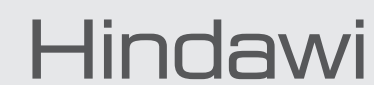

Submit your manuscripts at

http://www.hindawi.com
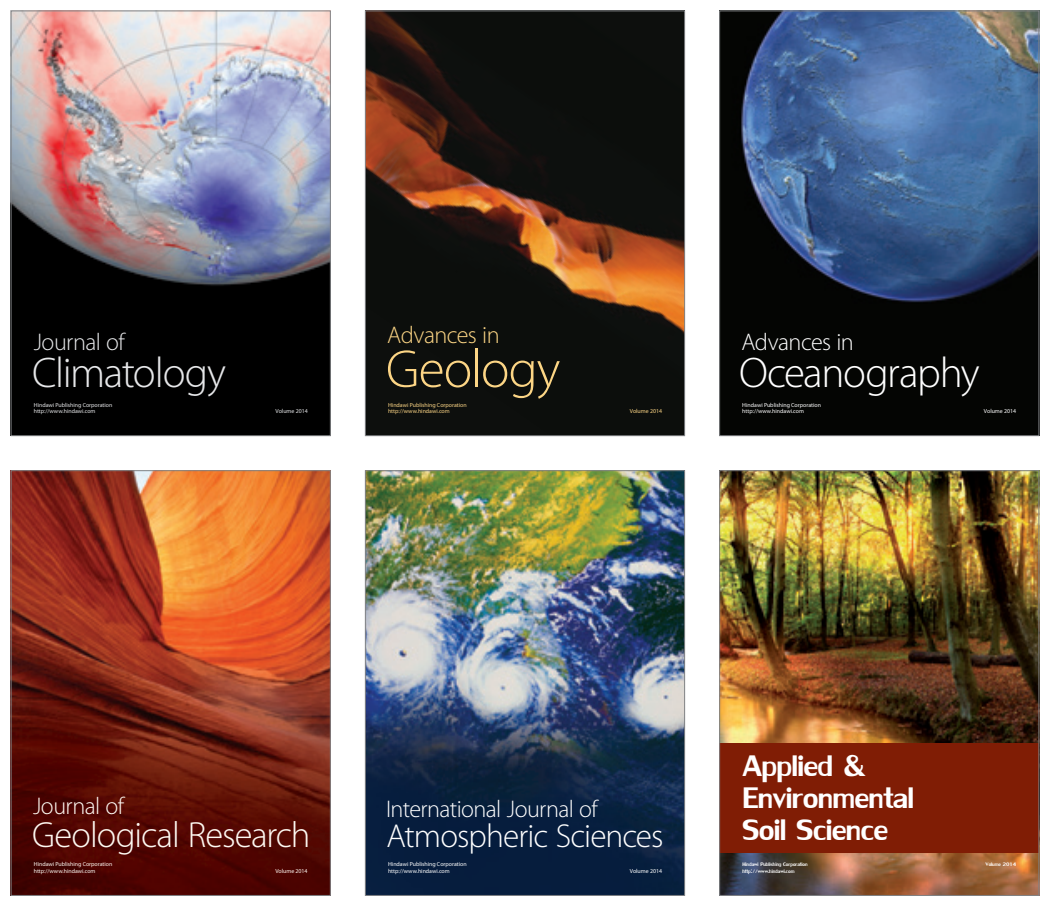
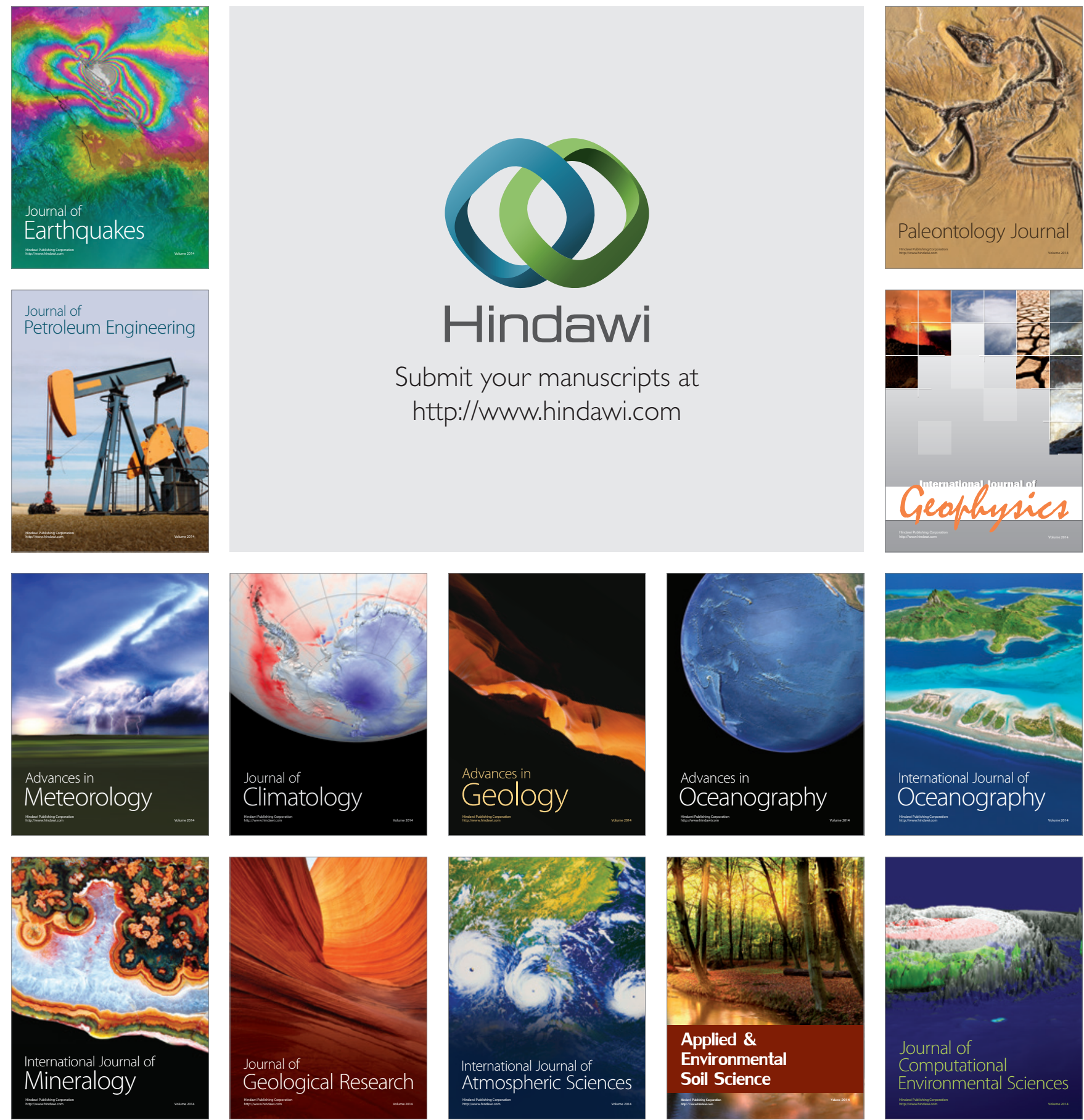